1666, en na de Mallabaerse den 29"u der maand Ady int jaer Coylan 841. ${ }^{1}$ ) Waren geteykent van de zyde van Trevancoor ende Coninginne van Atingen eenig Mallabaarsche caracters en uyt des Ed. Comp $^{\text {ind }}$ naem Siwert Backer.

\title{
CCCX. MAKASSAR.
}

\section{Januari 1667. $:$ )}

Op het eind van $1666 \mathrm{kwam}$ aan de gespannen verhoudingen tusschen de O. I. C. en Makassar een eind,cloordat de Hooge Regeering besloot, dit rijk den oorlog aan te doen. Een flinke vloot onder leiding van Cornelis Speelman stak den 24 November in zee (zie verder hierachter

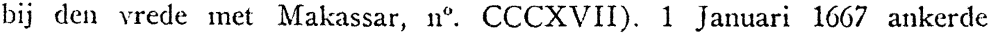
men bij het eiland Moena. Het bleek daar, dat de stad Boeton door de Makassaren werd belegerd. Speelman bond den strijd aan en 4 Januari gaf het Makassarsche leger zich over en de Nederlanders namen bezit van het vijandelijk kamp. (Stapel, Bongaais Verdrag, bldz. 93, v.v. en de daar aangehaalde litteratuur; Dagh-Register 1666-1667, bldz. 258, v.v.).

Artijculen waarop geaccordeert is tusschen d'E. Heer Cornelis Speelman, admiraal etc" van wegen de Hooge Regeringe van India op Batavia, met crain Bonto Marano, ${ }^{3}$ ) admiraal van wegen den cooningh ende regeringe van Macassar, mitsgaders radia Bima $^{4}$ ) ende radia Loubou, ${ }^{5}$ ) soo als volght.

Eerstelijk beloven bovengenoemde crain Bonto Marano, radia Bima en radja Loebou hun met het gantsche Macassarse leger, althans gelegen in de negerij Bougij op het eijlandt Bouton ende met des E. Comp's magt belegert, te onderwerpen ende stellen in handen van de E. Compagnie met alle de vaartuijgen, wapenen, spijse, alle andere middelen van goudt, silver en juwelen, slaven en slavinnen, niets ter weereldt uijtgesondert, en dat op genade en ongenade, ter discretie

1) Coilam (Canter Visscher, bldz. 434).

") Uit het Contractboek. In het Contractboek staat in margine „Bouton”, wat niet juist is.

:) Karaeng Bonto Mararano. - Hier wordt dus deze naam juister geschreven dan gewoonlijk (Monte marano). Vgl. Stapel, bldz. 107, noot 1) en 108.

4) Radja van Bima, die Makassar hulp verleende. Vgl. echter Stapel, bldz. $112,113$.

5) Radja van Loewoe, aan Makassar vasalplichtig. Deze vorsten waren de drie voornaamste hoofden van het Makassaarsche leger. 
van den overwinner, die uijt pure goetheijt haar verseeckert van haar leven, ende te bevrijden van alle mishandelinge ende misbruijck navolgens de Christelijcke manieren en sedigheijt.

Ten tweeden sullen zij tot begeren van de E. Compagnie promt en sonder enig dilaij hebben afte setten haare gelastigde; met of sonder onse scheeps of vaartuijgen magt, ${ }^{1}$ ) tot de 't sestig oorlogs prauwen, door hun 't haarder eerste aencomste tot Bouton onder 't commando van Dammanghaga(?) uijtgesonden, om de negerijen langs de buijten liust van 't eijlandt Bouton te vermeesteren ende ruineren, deselve mits desen als dependent van 't leger ook onderstellende, als vooren op genade ende ongenade ter discretie voor soo veel het in haare magt is.

Des heeft de heer Admiraal belooft de voorschreven crains Bontomarano, Bima en Loubou niet weder te stellen in handen of ondert gebiet van den coningh van Macassar, maar de twee laatste in haar eïjgen landt, onder voorwaerden, met d'E. Compagnie daar over te maacken ${ }^{2}$ ) ende den eersten in het lant van de een der twee voorschreven of wel bij de Bougijs ${ }^{3}$ ) ter keure van de E. Heer Admiraal, mede onder sodanige conditien, als in der tijt onderlingen sullen worden beraampt, behoudens dat sij of gene van de hare oijt of $f$ immermeer haar oock weder sullen mogen begeven tot dienst of believen van den coningh van Macassar.

Ende tot naarkominge van 't gene hier boven van wegens de overwonnene belooft staat, soo blijven de voorschreven drie overheeren vant leger als ostagieren, ${ }^{4}$ ) tot (lat sij en het gantsche leger ontwapent ende alle effecten hier voren vermeld in handen van den overwinner overgelevert sullen sijn.

Onderstont: aldus gedaen en gecontracteert in 't jaght Muijsenburgh, leggende ter rheede voor de negerije Bougij op 't eijlant Bouton ende in besettinge van het Macassarse leger, den 4 " Januarij cles jaars 1667. Was geteeckent Cornelis Speelman, en met Macassarse charackters de namen der bovengenoemde drie radjas. Lager stont: ons ten overstaan, die oock onder eede connen getuijgen, dat den inhoude deser de Crains bovengeschreven wel en overvloedigh in de Maleijtse tale uijtgelegt en vertaelt, mitsgaders dat het oock de regte cincere verhandelinge geweest is, alsoo wij present, en

1) De zin is hicr niet duidelijk.

2) Zie hierachter.

3) Boegineezen: toen voor een deel onze bondgenooten.

t) Gijzelaars. 
aanhourders van 't genegotieercle geweest zijn, en noch ondertekent: Maximiliaan de Jong, ${ }^{1}$ ) de naem van Radia Bougijs ${ }^{2}$ ) in sijn tale, D. van der Straten, Cristiaen Poolman, 't merk van Cap" Joncker, Gerrit den Back ${ }^{3}$ ) en in het Maleijts de naan van dien ${ }^{4}$ ) schrijver.

\section{MOLUKKEN.}

\section{Maart 1667. ")}

Saif Oedien, die in 1657 ,alleen door toedoen der .E. Maatschappij” sultan van Tidore was ,gekozen tegen de oude Molukse costumen, en rijk-wetten" en daardoor zijn "ouder broeder, Goranja” van diens rechten had beroofd, was cen ,vorst van veel verstand", maar volgens de onzen ,zeer kregelig, licht-geraakt, en zeer eigen-zinnig". (Vgl. hiervóór, bldz. 338). Niet te verwonderen, dat de O. I. C. er op gesteld was, de verhoudingen zoo scherp mogelijk te regelen, vooral ,in opzicht van de specerijen". Ofschoon reeds vroegrer overeenkomsten met hem waren gesloten, nam men de gelegenheid waar toen deze kwam, om een verdrag te sluiten, ,daar bij een weg gebaant” werd, „om zijne kregeligen aart wat beter, dan wel bevorens, te kumnen temmen". (Valentijn, I, Moluccos, bldz. 106, 109). Deze gelegenheid kwam met Speelman's expeditie tegen Makassar. Van Boeton (zie hiervóór, bldz. 346) vertrok Speelman naar de Molukken en sloot dáár onderstaand verdrag met Tidore. (Stapel, bldz. 96, 118, v.v.), hetwelk Tidore geheel aan de O. I. C. onderwierp.

Articulen ende voorwaarden, waarop den grootmagtigen Ceijfoedijn, coning van Tidor, en sijne Grooten voor haar ende haare subjecten en nacomelingen ter eenre, en den Heere Cornelis Speelman, Superintendent etc", in den name van den Ed. Heer Gouverneur Generael Joan Maatsuijclier ende de Heeren Raden van India, representerende de hoogste magt en authoriteijt van de Generale Nederlandsche Verenigde Geoctroijeerde Oostindische Compagnie in deze landen, ter andere zijden, voor eeuwigh en altoos geaccordeert, verdragen en overeengecomen zijn in maniere als hier onder geschreven.

1) Vg1. Stapel bldz. 96.

2) Aroe Palakka? (Vgl. Stauel, bldz. 106, v.v.).

3) Zie over de onderteekenaars Stapel, bldz. 97, v, 107.

4) "Den":

5) Uit het Contractboek. - Ook bij Valentijn, I, Moluccos, bldz. 109 v.v. 